\author{
P. Bareka, E. Katopodi, G. Kamari \& D. Phitos
}

\title{
Karyosystematic study of some taxa from the Ionian floristic region (Greece). I
}

\begin{abstract}
Bareka, P., Katopodi, E., Kamari, G. \& Phitos, D.: Karyosystematic study of some taxa from the Ionian floristic region (Greece). I. - Fl. Medit. 28: 85-97. 2018. — ISSN: 1120-4052 printed, 2240-4538 online.

A karyosystematic study of five characteristic taxa from the Ionian Islands (Greece) is presented. The cytogeography of Centaurea subciliaris is commented. The chromosome number of a newly studied Teucrium halacsyanum population from Lefkada island is given. The taxonomic position of Viola alba s. 1. is also discussed and a microphotograph (for the first time) of its karyotype from Lefkada island is provided. The chromosome number and karyotype morphology of Moraea mediterranea and Crocus speciosus subsp. speciosus are confirmed on material from Lefkada island and the presence of the latter in the island is referred for the first time.

Key words: Centaurea subciliaris, Crocus speciosus, Moraea mediterranea, Teucrium halacsyanum, Viola alba, cytology, distribution, taxonomy.
\end{abstract}

\section{Introduction}

The latter two authors of this publication already since 1966, among other research interests, initiated the study of the flora of the Ionian Islands in close collaboration with their good friend and collaborator Jürgen Damboldt (1937-1978), Professor in Systematic Botany of the Freie University of Berlin.

In recent years, W. Gutermann (Wien) and his colleagues have also extensively studied the flora of the Ionian Islands. In 2016, the results of this study, titled "Flora Ionica", were published as a comprehensive list of floristic findings from all the Ionian islands (Flora Ionica Working Group 2016-onwards). However, as is usually the case with the rich native flora of Greece, new floristic elements are constantly being added to the existing ones, and surprises are never missing (Phitos \& al. 2016).

The present publication is one more contribution to the flora of the Ionian floristic region. The given information concerns five taxa found on the island of Lefkada. Four of them also appear in other Ionian islands and belong to the corresponding floristic region. However, Crocus speciosus M. Bieb. subsp. speciosus, known to be distributed in locations of mainland Greece, is found for the first time in the Ionian region and specifically on the island of Lefkada. 
These new floristic findings confirm the need for a further study of the flora and vegetation of the Ionian Islands, which the last two authors of this publication have steadily pursued over several decades. We estimate that this is particularly true for the island of Lefkada with its mountainous geomorphology and a coastline with many sandy places, creating a diversity of important habitats.

The above data for the five studied taxa are supplemented for the first time by cytogeographical information. It should be mentioned that previous karyological investigations on plants from the Ionian Islands and especially from Lefkada have also been made by Artelari \& Kamari (1986), Kriemadi \& al. (2002), Bareka \& al. (2006) and Samaropoulou $\&$ al. (2013).

\section{Material and methods}

Living plants of the studied taxa were collected from several locations of the Ionian area (Table 1) and cultivated at the University of Patras and the Agricultural University of Athens. Vouchers are deposited in Herb. Phitos \& Kamari (UPA).

Chromosome counts were obtained from root tip metaphases, using the squash technique (Östergren \& Heneen 1962) with some small modifications. Chromosome plates were observed with Zeiss Axiophot photomicroscope.

Chromosome terminology follows Levan \& al. (1964), Stebbins (1971) and Kamari (1976), taking into consideration comments and suggestions by Sybenga (1959), Bentzer \& al. (1971) and Favarger (1978).

\section{Results and discussion}

Centaurea subciliaris Boiss. \& Heldr. s. 1. (Asteraceae)

Centaurea subciliaris, an endemic species of the Ionian flora, grows on the islands of Cephalonia and Lefkada (Fig. 1A), as well as on the opposite Akarnanika Ori (Mt. Boumistos and Mt. Perganti) of mainland Greece (Prefecture Aetolia-Akarnania).

Centaurea subciliaris has been described by Boissier \& Heldreich (in Boissier 1875) from the island of Cephalonia. According to Matthäs (1976), the plants of Mt. Boumistos form a separate subspecies, i.e. subsp. acarnanica Matthäs. Greuter (2003) upgraded subsp. acarnanica to species level as Centaurea acarnanica (Matthäs) Greuter. We think that the morphological differences of the plants of Cephalonia from those of Mt. Boumistos are not significant enough to distinguish them into two species, however, we expect that the final conclusions of the ongoing, comprehensive study of the populations of $C$. subciliaris s. 1. in the whole Ionian region, will shed more light.

With regard to the nomenclature, it should be noted that even though Centaurea subciliaris is reported by Dimopoulos \& al. (2013) as Centaurea alba subsp. subciliaris Boiss. $\&$ Heldr. (Dostál), it is known that $C$. alba grows only in the western Mediterranean area (Iberian Peninsula and southern France), while the Italian and Balkan populations, which are referred to as C. alba (Dostál 1976), belong, in fact, to C. deusta Ten. (López \& Devesa 2011, López-Vinyallonga \& al. 2015). 
Table 1. Chromosome number, locality and collectors of studied taxa.

\begin{tabular}{|c|c|c|c|}
\hline Taxon & $\begin{array}{c}\text { Chromosome } \\
\text { number }\end{array}$ & Locality & Collectors \\
\hline $\begin{array}{l}\text { Centaurea } \\
\quad \text { subciliaris subsp. } \\
\text { subciliaris }\end{array}$ & $2 n=2 \mathrm{x}=18$ & $\begin{array}{l}\text { Ins. Kephalonia, Mt. Aenos, } \\
\text { at summit Chionistra, alt. } \\
1600 \mathrm{~m}\end{array}$ & $\begin{array}{l}\text { G. Kamari, G. } \\
\text { Lisitsa, S. } \\
\text { Moschopoulou \& K. } \\
\text { Volteras, no } 29013\end{array}$ \\
\hline ” & $2 n=4 x=36$ & $\begin{array}{l}\text { Ins. Kephalonia, at the } \\
\text { lowlands of Mt. Aenos, } \\
\text { above the village Michata, } \\
\text { alt. ca. } 450 \mathrm{~m}\end{array}$ & $\begin{array}{l}\text { D. Phitos, G. Kamari } \\
\text { \& G. Ismailos, no } \\
29000\end{array}$ \\
\hline$”$ & $2 n=2 \mathrm{x}=18$ & $\begin{array}{l}\text { Ins. Lefkada, Mt. Mega } \\
\text { Oros, close to the village } \\
\text { Eglouvi and Agios Donatos, } \\
\text { alt. } 600-650 \mathrm{~m}\end{array}$ & $\begin{array}{l}\text { D. Phitos, G. Kamari } \\
\text { \& E. Katopodi, no } \\
29138\end{array}$ \\
\hline$"$ & $2 n=4 x=36$ & $\begin{array}{l}\text { Ins. Lefkada, close to the } \\
\text { villlage Chortata, at the } \\
\text { place named Paraspori, alt. } \\
668 \mathrm{~m}\end{array}$ & $\begin{array}{l}\text { D. Phitos, G. Kamari } \\
\text { \& E. Katopodi, no } \\
29134\end{array}$ \\
\hline $\begin{array}{l}\text { Centaurea } \\
\text { subciliaris subsp. } \\
\text { acarnanica }\end{array}$ & $2 n=4 x=36$ & $\begin{array}{l}\text { Sterea Ellas, Akarnanika } \\
\text { Ori, Mt. Perganti, alt. ca. } \\
1090 \mathrm{~m}\end{array}$ & $\begin{array}{l}\text { D. Phitos \& G. } \\
\text { Kamari, } \\
\text { no } 28075\end{array}$ \\
\hline $\begin{array}{l}\text { Crocus speciosus } \\
\text { subsp. speciosus }\end{array}$ & $2 n=2 x=18$ & $\begin{array}{l}\text { Ins. Lefkada, Mt. Elati, alt. } \\
\text { ca. } 1000 \mathrm{~m}\end{array}$ & E. Katopodi s.n. \\
\hline $\begin{array}{l}\text { Moraea } \\
\quad \text { mediterranea }\end{array}$ & $2 n=4 \mathrm{x}=24$ & $\begin{array}{l}\text { Ins. Lefkada, at the northern } \\
\text { sandy place named } \\
\text { Gyrapetra }\end{array}$ & $\begin{array}{l}\text { D. Phitos, G. Kamari } \\
\text { \& E. Katopodi, no } \\
29209\end{array}$ \\
\hline ” & $2 n=4 x=24$ & $\begin{array}{l}\text { Ins. Kephalonia, supra sinu } \\
\text { Lagadakia, alt. ca. } 20 \mathrm{~m}\end{array}$ & $\begin{array}{l}\text { D. Phitos \& } P \text {. } \\
\text { Minetos, no } 29255\end{array}$ \\
\hline $\begin{array}{l}\text { Teucrium } \\
\text { halascyanum }\end{array}$ & $2 n=2 \mathrm{x}=32$ & $\begin{array}{l}\text { Ins. Lefkada, from the } \\
\text { suburban area of the city } \\
\text { Lefkada }\end{array}$ & $\begin{array}{l}\text { D. Phitos, G. Kamari } \\
\text { \& E. Katopodi, no } \\
29292\end{array}$ \\
\hline ” & $2 n=2 \mathrm{x}=32$ & $\begin{array}{l}\text { Sterea Ellas, Prov. Aetolia- } \\
\text { Akarnania, Mt. Varasova, } \\
\text { alt. ca. } 5 \mathrm{~m}\end{array}$ & $\begin{array}{l}\text { G. Kamari \& E. } \\
\text { Liveri, no } 29326\end{array}$ \\
\hline $\begin{array}{l}\text { Viola alba } \\
\text { subsp. thessala }\end{array}$ & $2 n=2 \mathrm{x}=20$ & $\begin{array}{l}\text { Ins. Lefkada, gorge of } \\
\text { Melissa, alt. 200-250 m }\end{array}$ & $\begin{array}{l}\text { D. Phitos, G. Kamari, } \\
\text { E. Katopodi \& B. } \\
\text { Lazaris, no } 29262\end{array}$ \\
\hline
\end{tabular}

Additionally, our doubts, regarding the presence of Centaurea subciliaris in Bulgaria (Greuter \& Raab-Straube 2008) were proven to be justified, based on the examination of the photographs of three herbarium specimens from Mt. Stavryanka of Bulgaria (leg. D. Delipavlov, I. Cheshmedziev \& M. Popova 1980) from the Herbarium Instituti Agriculturae "V. Kolerov" - Plovdiv, which had been identified as Centaurea subciliaris. All three specimens, certainly, belong to the subsect. Phalolepis (Cass.) N. Garcia, Hilpold, Susanna \& Vilaters. However, the branching of the Bulgarian plants, the shape of the basal leaves and the stem, as well as the bracts of the involucres, are distinctly different from the corresponding features of $C$. subciliaris plants from the Ionian floristic region. 
Bareka \& al.: Karyosystematic study of some taxa from the Ionian floristic ...
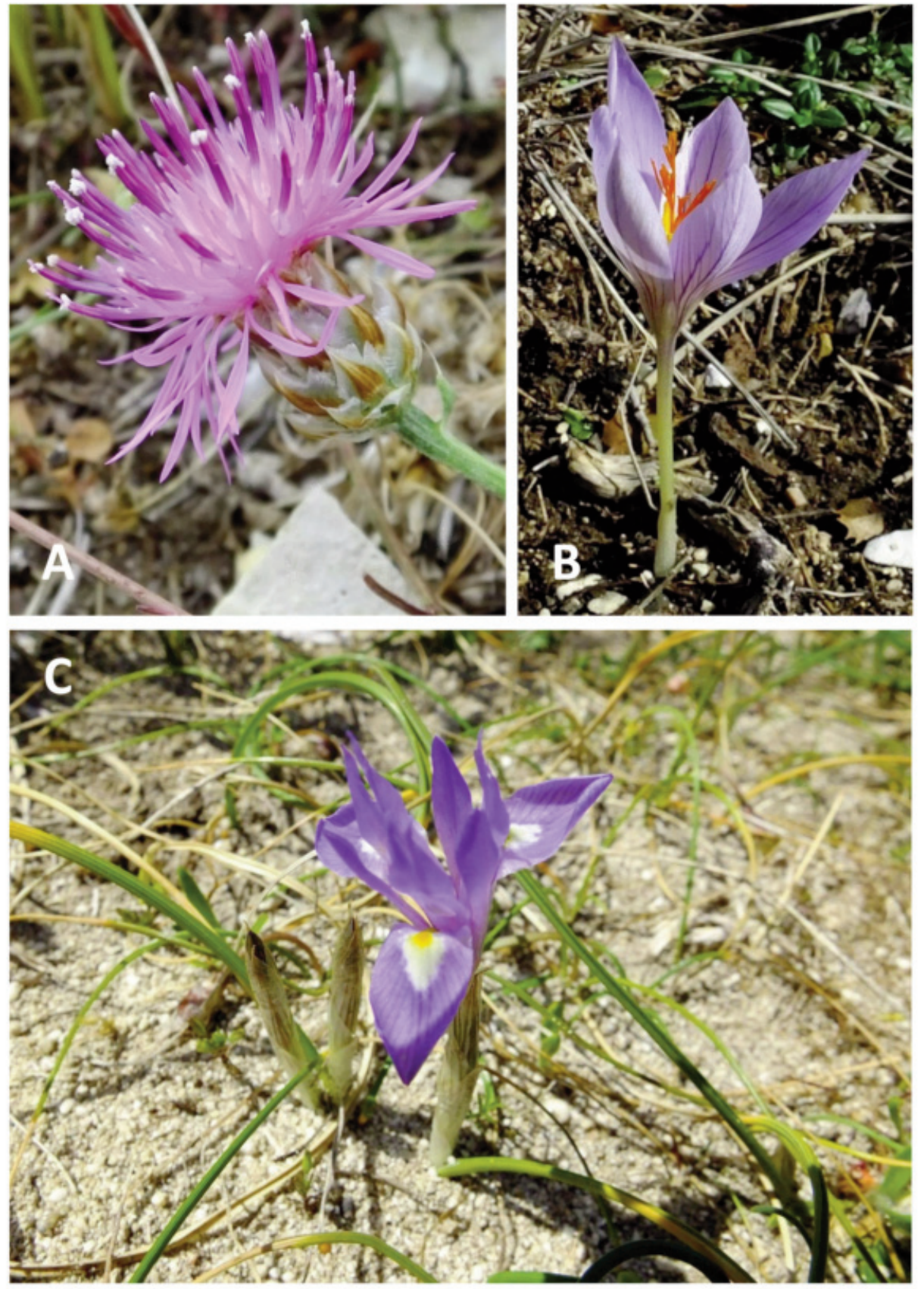

Fig. 1. Studied taxa from Lefkada island: A, Capitula of Centaurea subciliaris s. 1. from the place named Paraspori, close to the village of Chortata; $\mathbf{B}$, individual of Crocus speciosus subsp. speciosus from Mt. Elati; C, Moraea mediterranea from the northern sandy area, at the place Gyrapetra. 
Karyology

The chromosome number of Centaurea subciliaris from Cephalonia island was initially given by Phitos \& Damboldt (1971 \& 1985) and later by Samaropoulou \& al. (2013). In these studies, the diploid $2 n=18+0-2 \mathrm{~B}$, as well as the tetraploid number $2 n=4 \mathrm{x}=36+$ $0-4 \mathrm{~B}$, was found in plants from Mt. Aenos at 1300-1596 $\mathrm{m}$ a.s.1. In individuals from the foot of the mountain (350-450 m a.s.1.), only the diploid number $2 n=18+0-2 \mathrm{~B}$ was counted.

Matthäs (1976) reports the same results as those by Phitos \& Damboldt (1971) for the typical Centaurea subciliaris from Cephalonia and, additionally, gives the tetraploid number $2 n=4 \mathrm{x}=36+4 \mathrm{~B}$ for $C$. subciliaris subsp. acarnanica from Mt. Boumistos (Akarnanika Ori). For the typical subspecies, originating from the island of Lefkada, she mentioned only the diploid number $2 n=18$.

The somatic number $2 n=4 \mathrm{x}=36$ for the plants of $C$. subciliaris subsp. acarnanica from Akarnanika Ori (Mt. Perganti), is confirmed here. However, for the typical subspecies from Lefkada island we found $2 n=2 \mathrm{x}=18$ (Fig. 3A), also reported by Matthäs (1976), as well as $2 n=4 \mathrm{x}=36$ chromosomes (Fig. 3B) (see Table 1).

The karyotype of Centaurea subciliaris from Lefkada island is symmetrical with mostly submetacentric $(\mathrm{sm})$ to metacentric $(\mathrm{m})$ chromosomes, and one acrocentric pair (two in tetraploids) bearing small satellites (st-SAT) (Figs 3A \& 3B). The size of the chromosomes varies from 2.5 to $4.5 \mu \mathrm{m}$.

\section{Crocus speciosus M. Bieb. subsp. speciosus (Iridaceae)}

Crocus speciosus subsp. speciosus has a wide distribution from Caucasus and Crimea to N Iran and N \& C Turkey, extending westwards to the Balkan peninsula.

In Greece, the typical subspecies of Crocus speciosus was initially found by Phitos \& Kamari (1983) in the Prefecture of Ioannina, near the village Monodendri. Recently, it was also found on the island of Lefkada (Fig. 1B) by the second author. It should be noted that the presence of Crocus speciosus subsp. speciosus in Lefkada is, to date, unique for the Ionian Islands and constitutes the westernmost finding, regarding its distribution. In particular, two subpopulations of the taxon, located on the mountain range Stavrotas of Lefkada island, were studied here. One subpopulation exists at the top of Mt. Elati, at ca. $980 \mathrm{~m}$ a.s.1. and the other at the place Ammocampos close to the summit area of Mt. Profitis Ilias, ca. $950 \mathrm{~m}$ a.s.1.

Significant information on the presence of Crocus speciosus in Greece is also provided by Karamblianis \& Constantinidis (2009). According to them, subsp. speciosus has been found on Akarnanika Ori (Karamblianis 2007), as well as near the Monastery of Varnakovis of Prefecture Fokida (Karamplianis \& Constantinidis 2009).

So far, Crocus speciosus subsp. speciosus appears in Greece only in few (four) small populations. A typical example is the island of Lefkada, where each of the two subpopulations found there does not exceed 20 individuals. According to Karamblianis \& Constantinidis (2009), subpopulations on Akarnanika Ori, close to Romvou Monastery, amount to no more than 100 individuals, while only one individual was found at Varnakovis Monastery (Prefecture of Fokida)! Based on the up-to-date data on the state of the known subpopulations of subsp. speciosus and agreeing with Karamplianis \& Constantinidis 


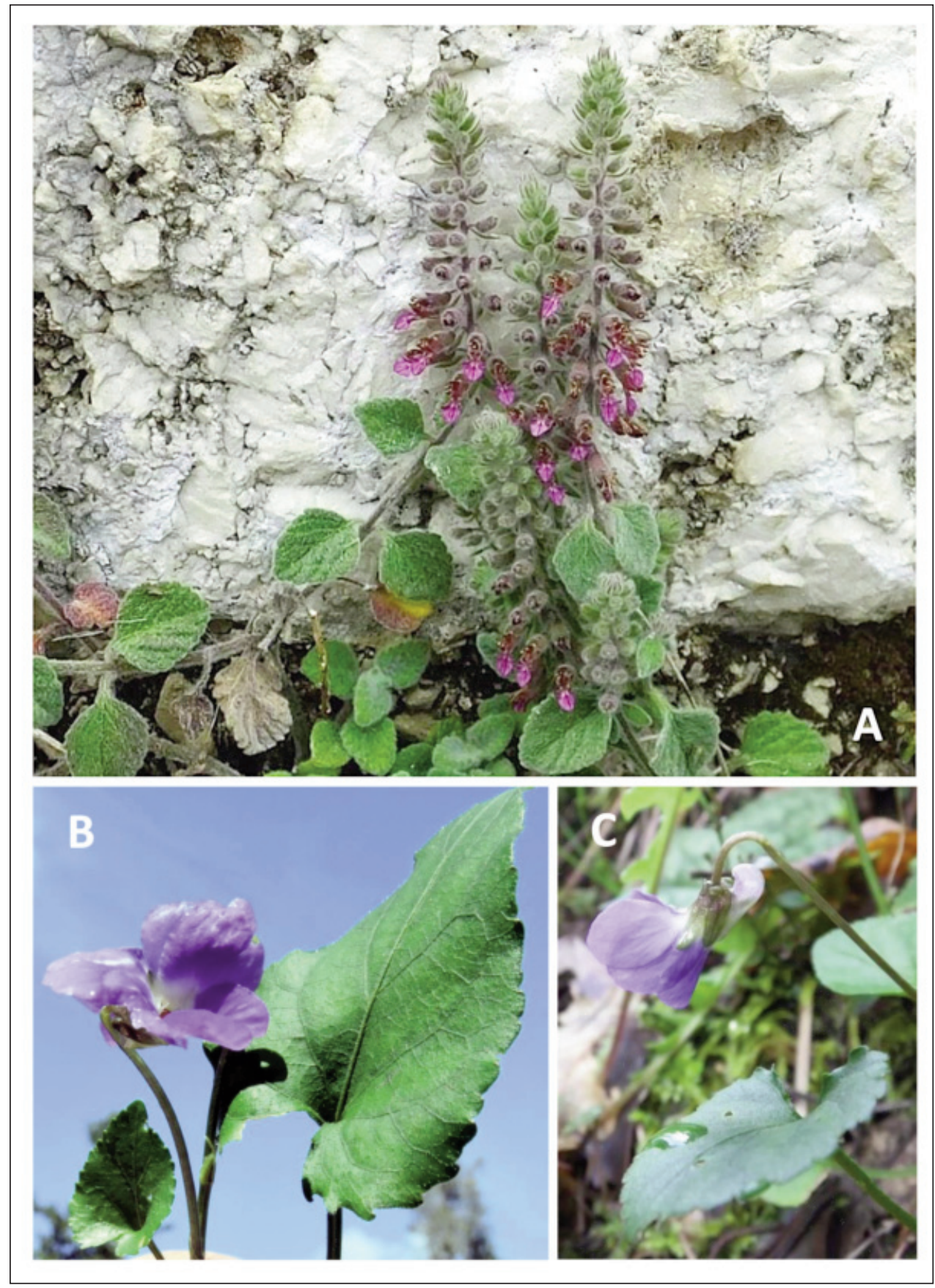

Fig. 2. Studied taxa from Lefkada island: A, flowering stems of Teucrium halacyanum from the cliffs close to the village Apolpaena; B, \& $\mathbf{C}$, flowers and leaves of Viola alba subsp. thessala from the gorge of Melissa. 
(2009) the taxon should be classified at least as Vulnerable (VU), according to the IUCN (2016) criteria [C2a(i); D1+2], even though the recorded sporadic appearance of the subspecies does not exclude its existence in other regions of Greece, possibly in the form of small populations. In any case, we think that this taxon needs immediate protection.

\section{Karyology}

The chromosome number of Crocus speciosus subsp. speciosus, in plants from Lefkada island was found to be $2 n=18$ (Fig. 3C).

The same chromosome number $2 n=18$ has also been reported by Phitos \& Kamari (1983) for plants from the Prefecture of Ioannina, close to the village Monodendri. This number corresponds to one of the various chromosome numbers $2 n=8,10,12,14,18$ given for C. speciosus by Brighton \& al. (1973), as well as by Mathew (1982).

The karyotype of Crocus speciosus subsp. speciosus is asymmetrical concerning the morphology of the chromosomes, with most chromosomes being submetacentric ( $\mathrm{sm}$ ) to acrocentric (st), varying in size between 8.5 to $19.6 \mu \mathrm{m}$ long.

\section{Moraea mediterranea Goldblatt (Iridaceae)}

Syn. Gynandriris monophylla Klatt

Moraea Mill., is mainly a South African genus, comprising ca. 130 species, including the 9 species of the well-known, small genus Gynandriris Parl. (Goldblatt 1998).

Moraea mediterranea is distributed in the Mediterranean area including the coastal areas of Libya and Egypt up to Sinai, as well as of Greece (Crete, some Cyclades islands, Rodos, Peloponnisos, Attiki etc.). As for the Ionian Islands, which are of particular interest here, $M$. mediterranea is not rare, especially in the coasts areas of Zakynthos, Cephalonia Lefkada and Kerkyra, where it sporadically forms small populations. Specifically on the island of Lefkada, its presence is known only from two small localities (Gyrapetra and Myloi) at the northern, sandy places of the island (Fig. 1C).

Moraea mediterranea usually grows on sandy or gravelly places or in open phrygana, at sea level, with the exception of Kriti, where it occasionally grows at up to $700 \mathrm{~m}$ a.s.l.

\section{Karyology}

Polyploidy is a common phenomenon in the genus Moraea, according to Goldblatt \& Manning (2013), leading to disploidy and subsequently to recent speciation events. Goldblatt (1980), also referring to the cytology of the two Moraea species found in Greece under their old names Gynandriris sisyrinchium Parl. and G. monophylla Klatt (the present names of these species are respectively Moraea sisyrinchium Ker Gawl. and M. mediterranea), notes that the karyotypes of the Greek populations from Attiki, were tetraploids ( $2 n$ $=4 \mathrm{x}=24)$, since the basic chromosomal number of the genus, is $\mathrm{x}=6$.

Indeed, the karyotype formula of the examined material here from Lefkada island appears also to be tetraploid, included $2 n=4 \mathrm{x}=4 \mathrm{~m}+16 \mathrm{sm}+4 \mathrm{st}=24$ chromosomes, medium in size, ranging in size between 6.8 and $15 \mu \mathrm{m}$ (Fig. 3E). It is noteworthy that in one or two pairs of submetacentric $(\mathrm{sm})$ chromosomes, secondary constrictions close to the centromere were visible, which, due to the applied squash technique during chromosome preparation, very often, got separated and look like B-chromosomes or very large satellites. 

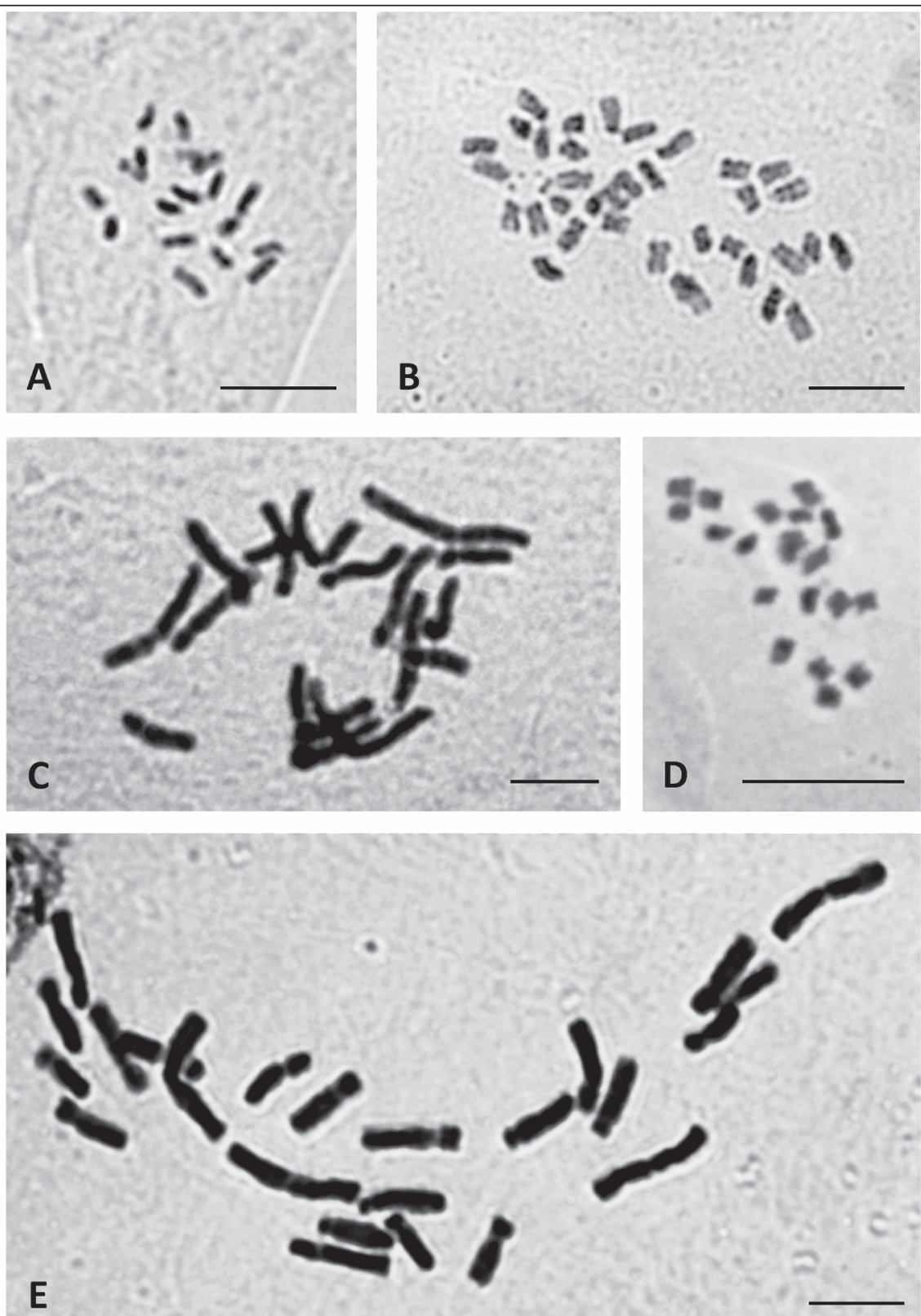

Fig. 3. Microphotographs of mitotic metaphase plates of the taxa studied from Lefkada island: A, Centaurea subciliaris subsp. subciliaris from Mt. Mega Oros, close to the vill. Eglouvi, $2 n=18$ and B, close to the village Chortata, at the place named Paraspori, $2 n=4 \mathrm{x}=36$; C, Crocus speciosus subsp. speciosus from Mt. Elati, $2 n=18$; D, Viola alba subsp. thessala from the gorge of Melissa, $2 n$ $=20 ; \mathbf{E}$, Moraea mediterranea from the northern sandy place named Gyrapetra, $2 n=4 \mathrm{x}=24$. - Scale bars $=10 \mu \mathrm{m}$. 


\section{Teucrium halacsyanum Heldr. (Lamiaceae)}

Teucrium halacsyanum (Fig. 2A), an endemic species of Flora Hellenica, can be considered as an important element of the Ionian floristic region, since its main distribution area includes all major Ionian Islands (Zakynthos, Cephalonia, Lefkada, Kerkyra) and some of the western and southern coasts of Sterea Hellas (Prefecture of Aetolia-Akarnania). The only locality of the species which is a bit distant from the Ionian Sea, is located in Vouraikos gorge (NW Peloponnisos), over Diakopto town (Heldreich, collection year 1899).

Teucrium halacsyanum has been described by Heldreich (1879) from the two neighbouring, relatively short mountains (locus classicus), i.e. Mt. Varasova and Mt. Klokova (Prefecture of Aetolia-Akarnania), the southern edges of which fall into the Patraikos Gulf, just across the city of Patras. The highest of these is Mt. Klokova or Paliovouna (known also Tafiassos in ancient times) with an altitude of $1037 \mathrm{~m}$ a.s.1., while Mt. Varasova is $914 \mathrm{~m}$ tall. Evinos River flows next to Varasova, merging with Patraikos Gulf, at the area where the ancient city of Chalkis was located. The name Chalkis is sometimes also used for Mt. Varasova.

Teucrium halacsyanum is a characteristic obligate chasmophyte found mostly on limestone cliffs. On Mt. Varasova it grows together with another endemic chasmophyte, Centaurea heldreichii Halácsy. An interesting and attractive divergence of Teucrium halacsyanum from its usual ecological habitat is its appearance (close to the city of Lefkada) on the walls of an abandoned old olive press about $100 \mathrm{~m}$ in length, on which more than 120 robust individuals of the species were counted.

\section{Karyology}

The somatic number of $2 n=32$ has already been given for Teucrium halacsyanum material from Kerkyra island (Quezel \& Contandriopoulos 1966) and from Cephalonia island (Damboldt 1976). In the present study, plants from the locus classicus, as well as from Lefkada island (close to the village Apolpaena and the suburban area of the city of Lefkada) were examined, showing the same chromosome number $(2 n=32)$ with very small (less than $0.5 \mu \mathrm{m}$ ) chromosomes with indistinct centromeres. For this reason, the karyotype morphology was not possible to be determined.

\section{Viola alba Besser s. 1. (Violaceae)}

Viola alba is a very variable, widespread and common species distributed in southern Europe and the adjacent parts of North Africa and West Asia.

The material of Viola alba s. 1. studied here comes from the island of Lefkada, specifically from Melissa gorge, at $330 \mathrm{~m}$ a.s.l. Due to the period of their collection (June 9, 2017), the collected plants from Lefkada, were in fruit. However, the morphology of the leaves and their hair, some mature capsules, as well as flower photos (kindly provided by Mr. B. Lazaris), constituted morphological features, capable to identify beyond doubt the plants in question (Figs. 2B \& 2C).

Marcussen (2003), after a thorough study of the Viola alba complex, using allozymes and morphometry, distinguished this species into three subspecies: $V$. alba subsp. alba, $V$. alba subsp. dehnhardtii (Ten.) W. Becker and $V$. alba subsp. cretica (Boiss. \& Heldr.) Marcussen, including the species $V$. scotophylla Jord. and $V$. thessala Boiss. \& Spruner as synonymes under the typical subspecies. 
We adopt in this work the classification of $V$. alba s. 1., reported by Livaniou-Tiniakou (1991), in her comprehensive PhD Thesis, based on a large number of specimens from the entire distribution area of those taxa in Greece. Livaniou-Tiniakou (1991) classifies Viola dehnhardtii and $V$. thessala as subspecies of $V$. alba, both very widespread in Greece, whereas the typical form of $V$. alba itself does not grow in Greece. In addition, the author preserves $V$. cretica, endemic to Crete, at species level due to its clear distinctive features from $V$. alba, but also by its isolated geographical distribution.

The taxonomic distinction of the two subspecies of $V$. alba occurring in Greece according to Livaniou-Tiniakou (1991) is as follows:

\section{V. alba subsp. dehnhardtii}

Leaves ovate-cordate, \pm obtuse with convex margins, usually light green to green. Flowers lilac with long, slender, acuminate, usually lilac spur. Capsule purplish, pubescent to glabrous.

\section{V. alba subsp. thessala}

Leaves long triangular-cordate, \pm acute with straight margins, usually deep green to green. Flowers lilac with short, stout, not acuminate, usually bluish-white spur. Capsule usually green, hairy.

We give a short description of the Viola alba s. 1. material from Lefkada (Figs 2B \& 2C): Leaves long triangular-cordate, \pm acute, $(2.5-) 4 \times 5-7 \mathrm{~cm}$, with straight margins, deep green; trichome very sparce; leaf blade glabrate with sparce hair mostly at the veins of the bottom surface of the leaves, $0.2-0.5 \mathrm{~mm}$ long. Flowers light blue to lilac with short spur antrose, bluish-white, rotund and not acuminate. Capsule light green, sparcely lanulose to hairy.

Therefore, the plants from Lefkada island, according to their morphological features, certainly belong to $V$. alba subsp. thessala, which is reported here for the first time from the island of Lefkada. Livaniou-Tiniakou (1991) mentioned that the widely distributed subsp. thessala in Greece, is also present on some other Ionian Islands (Cephalonia, Paxoi, Kerkyra), as well as on Akarnanika Ori (Mt. Boumistos).

\section{Karyology}

The karyotype of the studied population consists of $2 n=20$ chromosomes. The same chromosome number, as well as a respective karyotype drawing, was previously given by several authors for all the subspecies of Viola alba s. 1. from Greece (but not from Lefkada island) and other countries (Schöfer 1954; Schmidt 1961; Uhríková \& Májovsky 1978; Váchová \& Májovský 1978; Fernández Casado 1984; González Zapatero \& al. 1986; Montmollin 1986; Livaniou-Tiniakou 1991; Tiniakou 1991 \& 1992).

A microphotograph of the karyotype of Viola alba subsp. thessala is given here for the first time (Fig. 3D). Its karyotype is symmetrical, consisting of very small, mostly metacentric chromosomes, $\pm 1.5 \mu \mathrm{m}$ in size.

\section{Acknowledgements}

We express our particular gratitude to Prof. Anna Petrova (Sofia) for her immediate response to our request for photographic material of Centaurea subciliaris from Bulgaria. We also thank Dr. George Mitsainas (University of Patras) for checking the English language in our manuscript and Ms. Eleni 
Liveri, PhD Student, for her assistance with the karyological study. Finally, we sincerely thank our friends from Lefkada island, Mr. Nikos Grapsas and Mr. Babis Lazaris, for accompanying and helping us during the field work on this island.

\section{References}

Artelari, R. \& Kamari, G. 1986: A karyological study of ten Limonium species (Plumbaginaceae), endemic in the Ionian area, Greece. - Willdenowia 15: 495-513.

Bareka, P., Kamari, G. \& Phitos, D. 2006: Acis ionica (Amaryllidaceae), a new species from the Ionian area (W Greece, S Albania). - Willdenowia 36 (Special Issue): 357-366.

Bentzer, B., Bothmer, R. von, Engstrand, L., Gustafsson, M. \& Snogerup, S. 1971: Some sources of error in the determination of arm ratios of chromosomes. - Bot. Not. 124: 65-74.

Boissier, E. 1875: Centaurea subciliaris Boiss. \& Heldr. - P. 627 in: Boissier, E. 1875-1879, Flora Orientalis, 3. - Bâle, Lyon, Basel \& Genève.

Brighton, C. A., Mathew, B. \& Marchant, C. J. 1973: Chromosome counts in the genus Crocus (Iridaceae). - Kew Bull. 28(3): 451-464.

Damboldt, J. 1976: Beiträge zur Flora Ionica. VI. Karyologisch-systematische Bemerkungen zu einigen Labiaten. - Candollea 31: 273-281.

Dimopoulos, P., Raus, T., Bergmeier, E., Constantinidis, Th., Iatrou, G., Kokkini, S., Strid, A. \& Tzanoudakis, D. 2013: Vascular Plants of Greece. An annotated checklist. - Englera 31. - Berlin.

Dostál, J. 1976: Centaurea L. - Pp. 254-301 in: Tutin, T. G., Heywood, V. H., Burges, N. A., Moore, D. M., Valentine, D. H., Walters, S. M. \& Webb, D. A. (eds), Flora Europaea, 4. - Cambridge.

Favarger, C. 1978: Philosophie des comptages de chromosome. - Taxon 27: 441-448.

Fernández Casado, M. A. 1984: Estudios sobre el género Viola L. en la Península Ibérica. I. Cariología. - Fontqueria 5: 23-32.

Flora Ionica Working Group (2016 onwards): Flora Ionica - An inventory of ferns and flowering plants of the Ionian Islands (Greece). - Published at https://floraionica.univie.ac.at [Last accessed 13.3.2018].

Heldreich, Th. von 1879: Teucrium halacsyanum n. sp. Eine neue Teucrium-Art der griechischen Flora. - Oesterr. Bot. Z. 29(8): 241-242.

Greuter, W. 2003: The Euro+Med treatment of Cardueae (Compositae) - generic concepts and required new names. - Willdenowia 33: 49-61.

— \& Raab-Straube, E. von (eds) 2008: Med-Checklist: A critical inventory of vascular plants of the circum mediterranean countries, 2 Dicotyledones (Compositae). - Palermo, Geneve \& Berlin.

Goldblatt, P. 1980: Systematics of Gynandriris (Iridaceae), a Mediterranean-southern African disjunct. - Bot. Not. 133: 239-260.

- 1998: Reduction of Barnardiella, Galaxia, Gynandriris, Hexaglottis, Homeria, and Roggeveldia in Moraea (Iridaceae: Irideae). - Novon 8(4): 371.

— \& Manning, J. C. 2013: Review of chromosome cytology in Moraea (Iridaceae: Irideae): what chromosomes reveal about the evolution of the genus. - Bothalia 43(1): 43-54.

González Zapatero, M. A., Elena-Rosselló, J. A. \& Navarro Andrés, F. 1986: Estudios cariológicos en táxones del CW español pertenecientes a Querceta Ilicis. - Lazaroa 9: 61-68.

IUCN Standards and Petitions Subcommittee 2016: Guidelines for Using the IUCN Red List Categories and Criteria. Version 12. - Prepared by the Standards and Petitions Subcommittee. - Available at http://www.iucnredlist.org/documents/RedListGuidelines.pdf [Last accessed 1.2.2018]. 
Kamari, G. 1976: Cytotaxonomic study of the Crepis neglecta L. complex in Greece. - Ph.D. Thesis, University of Patras, Patras, Greece [In Greek].

Karamplianis, Th. 2007: Plant biodiversity of Akarnanika Ori mountain range in West Greece. - M.Sc. Thesis, Agricultural University of Athens, Athens. [In Greek].

\& Constantinidis, Th. 2009: Crocus speciosus M. Bieb. subsp. speciosus. - Pp. 336-337 in: Phitos, D., Constantinidis, Th. \& Kamari, G. (eds), The Red Data Book of Rare and Threatened Plants of Greece, 1(A-D). - Patras.

Kriemadi, E., Bareka, P. E. \& Kamari, G. 2002: Reports 1278-1283. [In Kamari, G., Blanché, C. \& Garbari, F. (eds), Mediterranean chromosome number reports -12]. - Fl. Medit. 12: 444-450.

Levan, A., Fredga, K. \& Sandberg, A. 1964: Nomenclature for centromeric position on chromosomes. - Hereditas 52: 201-220.

Livaniou-Tiniakou, A. 1991: Biosystematic study of the genus Viola, sectio Viola (Violaceae) in Greece. - Ph.D. Thesis, University of Patras, Patras, Greece. [in Greek with English summary].

López, E. \& Devesa, J. A. 2011: Revisión taxonómica del complejo Centaurea alba L. (Asteraceae) en la Península Ibérica. - Collect. Bot. (Barcelona) 30: 37-52.

López-Vinyallonga, S., López-Pujol, J., Constantinidis, Th., Susanna, A. \& Garcia-Jacas, N. 2015: Mountains and refuges: Genetic structure and evolutionary history in closely related, endemic Centaurea in continental Greece. - Mol. Phylogenet. Evol. 92: 243-254.

Marcussen, T. 2003: Evolution, phylogeography, and taxonomy within the Viola alba complex (Violaceae). - Pl. Syst. Evol. 237: 51-74. doi: 10.1007/s00606-002-0254-5

Mathew, B. F. 1982: The Crocus. A revision of the genus (Iridaceae). - London.

Matthäs, U. 1976: Zur Cytotaxonomie von Centaurea subciliaris Boiss. \& Heldr. (Sektio Phalolepis (Cass.) DC.) und verwandter Sippen im europäischen Mediterrangebiet. I. - Bot. Jahrb. Syst. 95(4): 418-434.

Montmollin, B. de 1986: Etude cytotaxonomique de la flore de la Crète. III. Nombres chromosomiques. - Candollea 41: 431-439.

Östergren, G. \& Heneen, W. K. 1962: A squash technique for chromosome morphological studies. - Hereditas 48: 332-341.

Phitos, D. \& Damboldt, J. 1971: Beiträge zur Flora Ionica. III Cytotaxonomische Bemerkungen zu einigen griechischen Compositen. - Ann. Naturhistor. Mus. Wien 75: 157-162.

— \& - 1985: Die Flora der Insel Kefallinia (Griechenland). - Bot. Chron. 5(1-2): 182-183.

— \& Kamari, G. 1983: Chromosome numbers in Crocus species (Iridaceae) from Greece. - Bot. Chron. 3(1-2): 30-32.

—, — \& Katsouni, N. 2016: Two rare taxa of the genus Fumaria (Fumariaceae) for the Greek flora. - Bot. Chron. 21: 83-90.

Quézel, P. \& Contandriopoulos, J. 1966: Teucrium corcyranum, espèce nouvelle de l'île de Corfou. - Bull. Soc. Bot. Fr. 113(5-6): 351-353.

Samaropoulou, S., Bareka, P., Artelari, R. \& Kamari, G. 2013: Karyological studies on some endemic and rare species of Kephalonia, Ionian Islands, Greece. - Fl. Medit. 23: 215-221. doi: 10.7320/FlMedit23.215

Schmidt, A. 1961: Zytotaxonomische Untersuchungen an europäischen Viola-Arten der Sektion Nominium. - Österr. Bot. Z. 108: 20-88.

Schöfer, G. 1954: Untersuchungen über die Polymorphie einheimischer Veilchen. - Planta 43: 537-563.

Stebins, G. L. 1971: Chromosomal evolution in higher plants. - London.

Sybenga, J. 1959: Some sources of error in the determination of chromosome length. - Chromosoma 10: $355-364$

Tiniakou, A. 1991: On some species of Viola sect. Viola from Greece. - Bot. Chron. 10: 661-665. 
— 1992: Reports (56-60). [In Kamari, G., Felber, F. \& Garbari, F. (eds), Mediterranean chromosome number reports - 2]. - Fl. Medit. 2: 232-235.

Uhríková, A. \& Májovsky J. 1978: Reports [In Löve, A. (ed.), IOPB chromosome numbers reports LXI]. - Taxon 27(4): 378-379.

Váchová, M. \& Májovský J. 1978: Reports [In Löve, A. (ed.), IOPB chromosome numbers reports LXI]. - Taxon 27(4): 381-382.

Addresses of the authors

Pepy Bareka ${ }^{1}$, Eleni Katopodi ${ }^{1}$, Georgia Kamari ${ }^{2}$ \& Dimitrios Phitos ${ }^{2}$,

${ }^{1}$ Laboratory of Systematic Botany, Faculty of Crop Science, Agricultural University of Athens, Iera Odos 75, GR-11855 Athens, Greece. E-mail: bareka@aua.gr; elkatopodi@hotmail.com

${ }^{2}$ Botanical Institute, Section of Plant Biology, Department of Biology, University of Patras, GR-26500 Patras, Greece. E-mail: kamari@upatras.gr; dphitos@upatras.gr 
